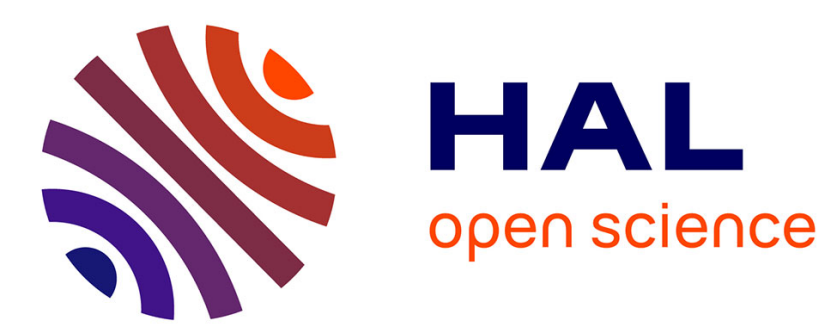

\title{
Depressed transient outward potassium current density in catecholamine-depleted rat ventricular myocytes
}

Gilles Bru-Mercier, Edith Deroubaix, Delphine Rousseau, Alain Coulombe, Jean-François Renaud

\section{- To cite this version:}

Gilles Bru-Mercier, Edith Deroubaix, Delphine Rousseau, Alain Coulombe, Jean-François Renaud. Depressed transient outward potassium current density in catecholamine-depleted rat ventricular myocytes. AJP - Heart and Circulatory Physiology, 2002, 282 (4), pp.H1237-H1247. 10.1152/ajpheart.00180.2001 . hal-02683189

\section{HAL Id: hal-02683189 \\ https://hal.inrae.fr/hal-02683189}

Submitted on 1 Jun 2020

HAL is a multi-disciplinary open access archive for the deposit and dissemination of scientific research documents, whether they are published or not. The documents may come from teaching and research institutions in France or abroad, or from public or private research centers.
L'archive ouverte pluridisciplinaire HAL, est destinée au dépôt et à la diffusion de documents scientifiques de niveau recherche, publiés ou non, émanant des établissements d'enseignement et de recherche français ou étrangers, des laboratoires publics ou privés. 


\section{Depressed transient outward potassium current density in catecholamine-depleted rat ventricular myocytes \\ Gilles Bru-Mercier, Edith Deroubaix, Delphine Rousseau, Alain Coulombe and Jean-François Renaud}

Am J Physiol Heart Circ Physiol 282:H1237-H1247, 2002. First published 23 November 2001;

doi: 10.1152/ajpheart.00180.2001

You might find this additional info useful...

This article has been cited by 1 other HighWire-hosted articles:

http://ajpheart.physiology.org/content/282/4/H1237\#cited-by

Updated information and services including high resolution figures, can be found at:

http://ajpheart.physiology.org/content/282/4/H1237.full

Additional material and information about American Journal of Physiology - Heart and Circulatory

Physiology can be found at:

http://www.the-aps.org/publications/ajpheart

This information is current as of July 12, 2016.

American Journal of Physiology - Heart and Circulatory Physiology publishes original investigations on the physiology of the heart, blood vessels, and lymphatics, including experimental and theoretical studies of cardiovascular function at all levels of organization ranging from the intact animal to the cellular, subcellular, and molecular levels. It is published 12 times a year (monthly) by the American Physiological Society, 9650 Rockville Pike, Bethesda MD 20814-3991. Copyright (C) 2002 the American Physiological Society. ISSN: 0363-6135, ESSN: 1522-1539. Visit our website at http://www.the-aps.org/. 


\title{
Depressed transient outward potassium current density in catecholamine-depleted rat ventricular myocytes
}

\author{
GILLES BRU-MERCIER, ${ }^{1}$ EDITH DEROUBAIX, ${ }^{1}$ DELPHINE ROUSSEAU, ${ }^{2}$ \\ ALAIN COULOMBE, ${ }^{1}$ AND JEAN-FRANÇOIS RENAUD ${ }^{1}$ \\ ${ }^{1}$ Département de Physiologie Cardiovasculaire et Thymique, Centre National de la Recherche \\ Scientifique, and Hôpital Marie Lannelongue, 92350 Le Plessis Robinson; and ${ }^{2}$ Laboratoire des \\ Lipides Membranaires et Fonction Cardiovasculaire, Institut National de la Recherche \\ Agronomique, Faculté de Pharmacie, 75270 Paris Cedex 06, France
}

Received 9 March 2001; accepted in final form 26 November 2001

Gilles Bru-Mercier, Edith Deroubaix, Delphine Rousseau, Alain Coulombe, and Jean-François Renaud. Depressed transient outward potassium current density in catecholamine-depleted rat ventricular myocytes. Am J Physiol Heart Circ Physiol 282: H1237-H1247, 2002. First published November 23, 2001; 10.1152/ajpheart.00180. 2001. - The effect of catecholamine depletion (induced by prior treatment with reserpine) was studied in Wistar rat ventricular myocytes using whole cell voltage-clamp methods. Two calcium-independent outward currents, the transient outward potassium current $\left(I_{\text {to }}\right)$ and the sustained outward potassium current $\left(I_{\text {sus }}\right)$, were measured. Reserpine treatment decreased tissue norepinephrine content by $97 \%$. Action potential duration in the isolated perfused heart was significantly increased in reserpine-treated hearts. In isolated ventricular myocytes, $I_{\text {to }}$ density was decreased by $49 \%$ in reserpine-treated rats. This treatment had no effect on $I_{\text {sus }}$. The $I_{\text {to }}$ steady-state inactivation-voltage relationship and recovery from inactivation remained unchanged, whereas the conductance-voltage activation curve for reserpine-treated rats was significantly shifted $(6.7 \mathrm{mV})$ toward negative potentials. The incubation of myocytes with $10 \mu \mathrm{M}$ norepinephrine for $7-10 \mathrm{~h}$ restored $I_{\mathrm{to}}$, an effect that was abolished by the presence of actinomycin D. Norepinephrine $(0.5 \mu \mathrm{M})$ had no effect on $I_{\text {to. }}$. However, in the presence of both $0.5 \mu \mathrm{M}$ norepinephrine and neuropeptide $\mathrm{Y}(0.1 \mu \mathrm{M}), I_{\text {to }}$ density was restored to its control value. These results suggest that the sympathetic nervous system is involved in $I_{\text {to }}$ regulation. Sympathetic norepinephrine depletion decreased the number of functional channels via an effect on the $\alpha$-adrenergic cascade and norepinephrine is able to restore expression of $I_{\text {to }}$ channels.

heart; denervation; adrenergic system; neuropeptide Y

TRANSIENT OUTWARD POTASSIUM CURRENT $\left(I_{\text {to }}\right)$ and sustained outward potassium current $\left(I_{\text {sus }}\right)$ play an important role in the regulation of action potential plateau amplitude and duration. Downregulation of these repolarizing currents increases the duration of the action potential (26) and may be involved in the genesis of arrhythmia by increasing the heterogeneity of action

Address for reprint requests and other correspondence: E. Deroubaix, Hôpital Marie Lannelongue, Département de Recherche Médicale, CNRS, 133 Ave. de la Résistance, 92350 Le Plessis Robinson, France (E-mail: edith.deroubaix@ccml.u-psud.fr). potential duration. $I_{\text {to }}$ amplitude is regulated by $\alpha_{1^{-}}$ agonists in rat ventricular myocytes $(2,4)$ and by $\beta$-adrenergic agonists in canine Purkinje fibers (27). Both effects inducing a decrease in $I_{\text {to }}$ are modulated by phosphorylation. A marked decrease in $I_{\text {to }}$ density has been reported in various cardiac diseases including subacute myocardial infarction (22), myocardial hypertrophy $(3,5)$, hypertrophic cardiomyopathy (25), Xlinked muscular dystrophy (32), diabetes (16), and the acute phase of Chagas' disease (31).

The mechanisms underlying the reduction of $I_{\text {to }}$ are not fully understood. Some lines of evidence suggest that the expression of $I_{\text {to }}$ is modulated by a trophic effect of the sympathetic nervous system. Three different models associating a decrease in $I_{\text {to }}$ with a decrease in sympathetic innervation have been studied. In Chagas' disease, the sympathetic nerve terminals are destroyed (23). This destruction occurs at the same time as a marked decrease in $I_{\text {to }}$ density during the acute phase of the disease $(14,31)$. In this model, a 24-h application of norepinephrine restored $I_{\text {to }}$ to normal values via adrenergic stimulation of protein kinase $C$ (PKC). Another model, inbred German shepherd dogs with inherited ventricular arrhythmia and a predisposition to sudden death, also showed a significant decrease in left ventricular $I_{\text {to }}$ density (12) in association with defects in sympathetic innervation (7). The third model concerns newborn rats treated with nerve growth factor, which accelerates cardiac sympathetic innervation, or with antibody directed against nerve growth factor, which delays cardiac sympathetic innervation. It has been suggested that the development of sympathetic innervation in this model depends strongly on the current density of $I_{\text {to }}$ during postnatal development of the rat heart (21).

The aim of this study was to investigate the effect of long-term catecholamine depletion on $I_{\text {to }}$ by determining $I_{\text {to }}$ in a model involving the "chemically denervated" rat heart. Chemical denervation was induced by reserpine treatment, which is known to decrease the

The costs of publication of this article were defrayed in part by the payment of page charges. The article must therefore be hereby marked "advertisement" in accordance with 18 U.S.C. Section 1734 solely to indicate this fact. 
amount of norepinephrine released into tissues by sympathetic nerve terminals $(20,38)$. We found that the depletion of endogenous norepinephrine by reserpine markedly decreased $I_{\text {to }}$ density, whereas $I_{\text {sus }}$ was unaffected. In these experimental conditions, the decreased in $I_{\text {to }}$ was reversed by the application of high $\alpha$-adrenergic agonist concentrations alone or by low concentration of $\alpha$-adrenergic agonist only if neuropeptide Y (NPY) was also present.

\section{METHODS}

Experimental animals. Animals were cared for and used in accordance with institutional guidelines. Two groups of animals were used: the control group (15 untreated rats +6 vehicle-treated rats) and the reserpine-treated group (24 rats). Male Wistar rats (200-350 g) were injected with reserpine every day for 6 days. A seventh injection was performed $2 \mathrm{~h}$ before the rats were killed. Reserpine $(20 \mathrm{mg})$ was dissolved in $0.5 \mathrm{ml}$ glacial acetic acid and $1 \mathrm{ml}$ propylene glycol brought to $20 \mathrm{ml}$ with distilled water such that, to obtain the desired final concentration, it was necessary to administer $1 \mathrm{ml}$ of reserpine solution per kilogram to each animal. Fresh reserpine solution was prepared daily. Control animals were either untreated or injected with vehicle only. Because the peak current density of $I_{\text {to }}$ measured at $+65 \mathrm{mV}$ from a holding potential of $-80 \mathrm{mV}$ was not significantly different from untreated and vehicle-treated rats, the data for these two groups were pooled. As it has been shown by Rice et al. (38) that the tissue contain only $4 \%$ the norepinephrine of controls after 3 days of treatment with reserpine and $3 \%$ after 7 days, we estimated that after 6 days of treatment with reserpine our animals were in steady-state conditions. This treatment induced a reduction in heart rate and in arterial blood pressure (19).

Determination of endogenous norepinephrine content. Norepinephrine was determined in the left ventricle as described by Eriksson and Persson (9). Norepinephrine was extracted from tissues at $+4^{\circ} \mathrm{C}$. Tissues were homogenized in the following solution $\left(1 \mathrm{ml} / 100 \mathrm{mg}\right.$ of tissue): $1 \mathrm{mg} / \mathrm{ml} \mathrm{Na}_{2}$ EDTA, $0.965 \mathrm{mg} / \mathrm{ml} \mathrm{H} \mathrm{H}_{2} \mathrm{O}, 3.5 \mathrm{ml}$ of $70 \% \mathrm{HClO}_{4}^{-}$per $100 \mathrm{ml}$, and $10 \mu \mathrm{g} / \mathrm{ml}$ dihydroxybenzylamine (DHBA) using a glass polytron probe. DHBA was used as the internal standard. Tissue homogenates were centrifuged, and the following chemicals were added to the supernatant: $100 \mathrm{mg}$ alumina, 1 $\mathrm{ml}$ Tris buffer $(1 \mathrm{M}), 50 \mu \mathrm{l}$ glutathione $(0.05 \mathrm{M})$, and $50 \mu \mathrm{l}$ EDTA (0.3 M); $\mathrm{pH}$ was adjusted to 8.6 with $\mathrm{NaOH}$. The tubes were shaken for $20 \mathrm{~min}$ and then centrifuged again. The supernatant was discarded, and the alumina pellet was washed with deionized water. Catecholamines were eluted from the alumina pellet by agitation for $2 \min$ in $200 \mu \mathrm{l}$ perchloric acid. The mixture was centrifuged for $10 \mathrm{~min}$, and the catecholamine content of the supernatant was determined by high-performance liquid chromatography using a Kontron 405 pump, a WISP model 712 automated sample injector, and a Lichrospher Merk 18C column $(5 \mu \mathrm{m}, 250 \times 4$ $\mathrm{mm}$ ). The flow rate was $1 \mathrm{ml} / \mathrm{min}$. An electrochemical detector (Kontron 405) with a sensitivity of $60 \mathrm{nA} / \mathrm{V}$ was used. Electrochemical detection was performed at the oxidation potential corresponding to norepinephrine. The amount of catecholamines was calculated with respect to the internal standard.

Action potential measurements. Action potential recordings were performed on isolated hearts perfused according to the Langendorff technique with constant pressure (70 $\mathrm{cmH}_{2} \mathrm{O}$ ). The isolated heart was continuously perfused with normal Tyrode solution maintained at $24.0 \pm 0.5^{\circ} \mathrm{C}$, through which $95 \% \mathrm{O}_{2}-5 \% \mathrm{CO}_{2}$ was bubbled. The Tyrode solution contained (in mM) $130 \mathrm{NaCl}, 5.6 \mathrm{KCl}, 0.6 \mathrm{NaH}_{2} \mathrm{PO}_{4}, 20$ $\mathrm{NaHCO}_{3}, 1.1 \mathrm{MgCl}_{2}, 2.15 \mathrm{CaCl}_{2}$, 2 sodium pyruvate, and 10 glucose. Hearts were electrically driven (2- to 3 -ms pulses) at a frequency of $2.5 \mathrm{~Hz}$, a frequency slightly higher than normal cardiac rhythm at $24^{\circ} \mathrm{C}$. Transmembrane action potentials were recorded from the epicardial surface of the left ventricle using standard floating microelectrodes (15-30 $\mathrm{M} \Omega$ ) and a M707 amplifier (WP Instruments). Action potentials were digitized at $20 \mathrm{kHz}$ using Acquis 1 software (BioLogic) on a personal computer (Pentium II, $233 \mathrm{MHz}$ ). They were then analyzed and printed on a Hewlett-Packard Laserjet III printer (Hewlett-Packard; San Diego, CA). The following parameters were determined: resting membrane potential, action potential amplitude, maximum upstroke velocity of the action potential, and action potential duration at 0 and $-60 \mathrm{mV}$.

Isolation of ventricular myocytes. Hearts were cannulated and subjected to retrograde perfusion via the aorta for $5 \mathrm{~min}$ at $37^{\circ} \mathrm{C}$ with standard Tyrode solution and then for $3 \mathrm{~min}$ with nominally $\mathrm{Ca}^{2+}$-free Tyrode solution. Enzymatic digestion was achieved by recirculating $50 \mathrm{ml} \mathrm{Ca}{ }^{2+}$-free Tyrode solution containing $2 \mathrm{mg} / \mathrm{ml}$ collagenase (type A, BoehringerMannheim), $5 \mathrm{mg} / \mathrm{ml} \mathrm{BSA}$, and $0.4 \mathrm{mg} / \mathrm{ml}$ hyaluronidase for 9-12 min. The ventricles were separated from the atria, cut into small pieces, and incubated for $5 \mathrm{~min}$ in Kraftbrühe (KB; high $\mathrm{K}^{+}$) solution with $5 \mathrm{mg} / \mathrm{ml}$ BSA at $37^{\circ} \mathrm{C}$. Cells were dispersed by gentle agitation of the tissue pieces, filtered, and centrifuged. The cells were resuspended in KB solution containing $5 \mathrm{mg} / \mathrm{ml} \mathrm{BSA}$ and $1 \mathrm{mg} / \mathrm{ml}$ protease (type XIV) and incubated for $15 \mathrm{~min}$ at $37^{\circ} \mathrm{C}$. The suspension was centrifuged; the cells were resuspended in KB solution and kept in this storage solution at $4^{\circ} \mathrm{C}$ for at least $1 \mathrm{~h}$ before use. A sample of the isolated cells was incubated in $0.5 \mathrm{mM} \mathrm{CaCl}_{2}$ Tyrode solution alone with norepinephrine $(0.5$ or $10 \mu \mathrm{M})$, or with NPY $(0.1 \mu \mathrm{M})$, or with actinomycin $\mathrm{D}(1.6 \mu \mathrm{M})$ in Tyrode solution for $7-10 \mathrm{~h}$ at $37^{\circ} \mathrm{C}$. The remaining cells were used immediately after the initial incubation in storage solution for patch-clamp experiments.

Solutions and drugs. The standard Tyrode solution contained (in mM) $135 \mathrm{NaCl}, 4 \mathrm{KCl}, 2 \mathrm{MgCl}_{2}, 1.8 \mathrm{CaCl}_{2}, 10$ HEPES, $1 \mathrm{NaH}_{2} \mathrm{PO}_{4}, 2.5$ sodium pyruvate, and 20 glucose; $\mathrm{pH}$ was adjusted to 7.4 with $\mathrm{NaOH}$. $\mathrm{Ca}^{2+}$-free Tyrode solution was identical except that $\mathrm{CaCl}_{2}$ was omitted. The storage solution (KB) contained (in $\mathrm{mM}$ ) $25 \mathrm{KCl}, 3 \mathrm{MgCl}_{2}, 10$ HEPES, 70 potassium glutamate, $10 \mathrm{KH}_{2} \mathrm{PO}_{4}$, 0.5 EGTA, 20 taurine, and 20 glucose; $\mathrm{pH}$ was adjusted to 7.4 with $\mathrm{KOH}$. For whole cell current recordings, the intracellular pipette solution contained (in $\mathrm{mM}$ ) 115 potassium aspartate, $10 \mathrm{KCl}$, $3 \mathrm{MgCl}_{2}, 10$ HEPES, 5 EGTA, 5 Mg-ATP, and 10 glucose; $\mathrm{pH}$ was adjusted to 7.2 with $\mathrm{KOH}$. For potassium current recordings, the external bath solution contained (in mM) 135 choline chloride, $1.1 \mathrm{MgCl}_{2}, 1.8 \mathrm{CaCl}_{2}, 0.1 \mathrm{CdCl}_{2}, 10 \mathrm{HEPES}$, 0.01 atropine sulfate, 0.001 ryanodine, and 10 glucose; $\mathrm{pH}$ was adjusted to 7.4 with $\mathrm{KOH}$. In these conditions, both $\mathrm{Na}^{+}$ and $\mathrm{Ca}^{2+}$ currents were abolished and the contribution of putative muscarinic and $\mathrm{Ca}^{2+}$-activated $\mathrm{K}^{+}$currents were minimal. All chemicals were purchased from Sigma.

Current recordings and statistical analysis. Ventricular myocytes were placed in petri dishes and superfused with Tyrode solution containing $0.5 \mathrm{mM} \mathrm{CaCl}_{2}$ and $10^{-6} \mathrm{M}$ ryanodine at room temperature $\left(20-25^{\circ} \mathrm{C}\right)$. A flow of solution (50-100 $\mu \mathrm{l} / \mathrm{min}$ ) from a series of piped outlets continuously superfused the cell used to make the recording. Ionic currents were recorded in the whole cell patch-clamp configuration with a RK300 amplifier (Bio-Logic). Patch pipettes 
(Pyrex 7740, Corning Glass; Corning, NY) were pulled on a two-stage puller (DMZ-Universal Puller, Zeitz Instruments). The pipettes were fire polished and had resistances of $2-3$ $\mathrm{M} \Omega$ when filled with pipette solution. A sequence of 10 depolarizing pulses, each of $10-\mathrm{mV}$ amplitude and $10-\mathrm{ms}$ duration, was applied to the cell membrane from $-80 \mathrm{mV}$ at a frequency of $10 \mathrm{~Hz}$. The capacitive current produced by these pulses was averaged, and cell membrane capacity was calculated as the ratio of the numerical integration of the averaged current transient (total charge) to the magnitude of the depolarizing pulse. Neither cell membrane capacitive current nor leakage current was compensated. Cell currents were digitized at $20 \mathrm{kHz}$ and analyzed after a numerical subtraction of the capacitive current using Acquis1 software (Bio-Logic).

$I_{\text {to }}$ and $I_{\text {sus }}$ were elicited by depolarizing pulses of 1 -s duration from a holding potential of $-80 \mathrm{mV}$ in $15-\mathrm{mV}$ increments between -40 and $+65 \mathrm{mV}$ at a frequency of 0.1 $\mathrm{Hz} . I_{\text {to }}$ was measured as the difference between peak current and steady-state current at the end of the test pulse. $I_{\text {sus }}$ was measured as the difference between steady-state current and the zero current level of the cell. Because maximum experimental values did not reflect maximum chord conductance, we determined chord conductance using a computer-calculated fit to a Boltzmann relation according to the equation

$$
G=G_{\max } /\left\{1+\exp \left[-\left(V_{\mathrm{m}}-\mathrm{V}_{0.5}\right) / k\right]\right\}
$$

where $G_{\max }$ is the maximum chord conductance, $G$ is the chord conductance calculated at the membrane potential $\left(V_{\mathrm{m}}\right), V_{0.5}$ is the potential at which the conductance is onehalf maximally activated, and $k$ is the slope factor, inversely proportional to the steepness of the activation curve. To determine the voltage dependence of $I_{\text {to }}$ inactivation, the membrane was held at various potentials in the range -110 to $+17.5 \mathrm{mV}$ (increment: $7.5 \mathrm{mV}$ ) for $2 \mathrm{~s}$ before applying a 1-s test pulse at a fixed voltage of $+25 \mathrm{mV}$. A theoretical Boltzmann function was fitted to the data using the nonlinear least-squares gradient-expansion algorithm of Marquardt. To investigate the recovery from inactivation of $I_{\text {to }}$, the current was activated and inactivated by a $750-\mathrm{ms}$ pulse at +60 $\mathrm{mV}$ from a holding potential of $-80 \mathrm{mV}$. This pulse was followed at various intervals $(4 \mathrm{~ms}-5 \mathrm{~s})$ by another identical pulse during which $I_{\text {to }}$ was measured. This double-pulse protocol was applied every $10 \mathrm{~s}$.

Pooled data are presented as means \pm SE of $n$ determinations (number of tested cells). The statistical significance of differences between groups was determined using Dunnett's test after one-way ANOVA, with $P<0.05$ considered significant.

\section{RESULTS}

Endogenous norepinephrine content of left ventricles. Table 1 shows the mean norepinephrine content of left

Table 1. NE content of the left ventricle for the various groups of animals

\begin{tabular}{lccc}
\hline \hline & & \multicolumn{2}{c}{ Treatment } \\
\cline { 3 - 4 } & $\begin{array}{c}\text { Control } \\
(n=4)\end{array}$ & $\begin{array}{c}\text { Vehicle } \\
(n=5)\end{array}$ & $\begin{array}{c}\text { Reserpine } \\
(n=5)\end{array}$ \\
\hline NE, ng/g & $681 \pm 57$ & $825 \pm 45(\mathrm{NS})$ & $22 \pm 6^{*}$ \\
$\%$ Control & 100 & 120.7 & 3.2 \\
\hline
\end{tabular}

Values are means $\pm \mathrm{SE} ; n=$ no. of animals. NE, mean norepinephrine content; NS, not significant. * Significantly different from control, $P<0.001$.

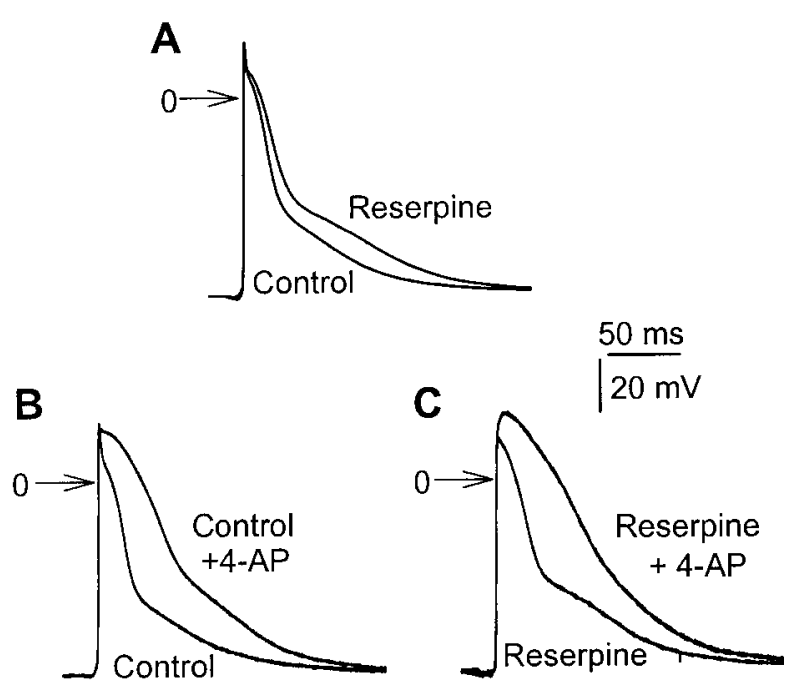

Fig. 1. Action potentials of the left ventricular isolated perfused heart. A: comparison of mean left ventricular action potentials recorded for vehicle-treated rats (control) and reserpine-treated rats (reserpine). Three animals were used in each group; 55 cells from control animals and 45 cells from reserpine-treated animals were averaged. $B$ and $C$ : examples of the effect of a 2-min perfusion of 4-aminopyridine (4-AP; $4 \mathrm{mM}$ ) on a control action potential from a vehicle-treated rat $(B)$ and on an action potential from a reserpinetreated rat $(C)$.

ventricles from the various groups of animals used in this study. Norepinephrine content was not significantly higher in vehicle-treated groups than in the control group, whereas reserpine treatment reduced the norepinephrine content of the left ventricle by $97 \%$.

Ventricular action potentials of the perfused heart. We first studied the effect of reserpine treatment on the action potentials of the isolated perfused rat heart. Figure $1 A$ shows the superimposition of the mean left epicardial ventricular action potential in vehicletreated (control) and reserpine-treated rats. The duration of the action potential was significantly longer in the reserpine-treated rat heart than in the control rat heart. There was no statistically significant difference in membrane resting potential between the reserpinetreated and control groups, whereas maximum action potential amplitude and maximum upstroke velocity of the action potential were significantly lower in the reserpine group. The action potential durations at 0 and $-60 \mathrm{mV}$ were significantly longer in reserpinetreated rats than in untreated rats (Table 2). The increase in action potential duration observed in reserpine-treated rats may result from a decrease in outward currents, an increase in inward currents, or both. We investigated the effect of $4 \mathrm{mM} \mathrm{4-aminopyridine}$ (4-AP), an inhibitor of $I_{\text {to }}$, on action potentials in control and in reserpine-treated animals (Fig. 1, $B$ and $C$ ). 4-AP caused a marked prolongation of action potential in both groups of animals. Action potential duration with 4-AP did not differ significantly between control and reserpine-treated cells [action potential durations at 0 and $-60 \mathrm{mV}$ were, respectively, $37.7 \pm 1.2$ and $107.4 \pm 5.1 \mathrm{~ms}$ in controls $(n=7)$ and $39.7 \pm 1.4$ and $112.8 \pm 3.1 \mathrm{~ms}$ in reserpine-treated rats $(n=8)]$. In 
Table 2. Action potential parameters of the vehicle-treated (control) and reserpine-treated left ventricular perfused heart

\begin{tabular}{llcccr}
\hline \hline & \multicolumn{1}{c}{$E_{\mathrm{r}, \mathrm{mV}}$} & $\mathrm{APA}, \mathrm{mV}$ & $V_{\max }, \mathrm{V} / \mathrm{s}$ & $\mathrm{APD}_{0}, \mathrm{~ms}^{2}$ & $\mathrm{APD}-60, \mathrm{~ms}$ \\
\hline Control & $-76.8 \pm 0.4$ & $99.1 \pm 0.8$ & $135.7 \pm 3.1$ & $9.2 \pm 0.4$ & $65.8 \pm 1.8$ \\
Reserpine & $-75.6 \pm 0.5(\mathrm{NS})$ & $93.0 \pm 0.7^{*}$ & $107.2 \pm 3.8^{*}$ & $13.6 \pm 0.6^{*}$ & 55 \\
\hline
\end{tabular}

Values are means $\pm \mathrm{SE} ; n=$ no. of cells tested. $E_{\mathrm{r}}$, resting membrane potential; APA, action potential amplitude; $V_{\max }$, maximum rate of rise of the action potential; $\mathrm{APD}_{0}$ and $\mathrm{APD}_{-60}$, action potential duration at 0 and $-60 \mathrm{mV}$, respectively. $*$ Significantly different from control, $P<0.001$.

this study, we focused on the role of $I_{\text {to }}$, which plays a critical role in action potential repolarization.

Transient and sustained outward currents. Figure $2 A$ shows representative families of current traces obtained with ventricular myocytes from control and reserpine-treated rats. To facilitate comparisons, we choose myocytes with nearly equal membrane capacitance values. Depolarization from a holding potential of $-80 \mathrm{mV}$ to membrane potentials more positive than $-10 \mathrm{mV}$ elicited rapidly activating transient outward currents that increased in amplitude with increasing depolarization. The peak current was reached within $10 \mathrm{~ms}$ for high levels of depolarization and the time to peak decreased with increasing membrane depolarization. The transient outward current decayed quite rapidly over the first $100 \mathrm{~ms}$ and then more slowly, indicating that two kinetic components contribute to the time-dependent fraction of $I_{\text {to }}$. At the end of the 1-s
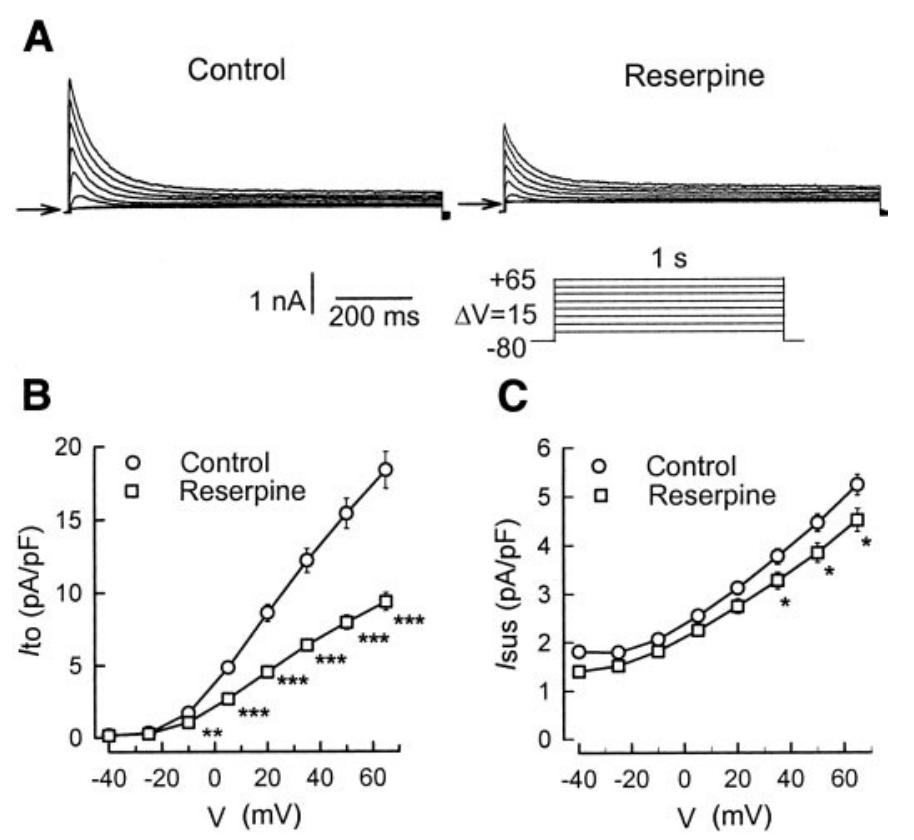

Fig. 2. Effect of reserpine treatment on outward potassium currents. $A$ : effect of reserpine treatment on families of outward currents. Cell membrane capacitance was 142 and $151 \mathrm{pF}$, respectively, for vehicletreated (control) and reserpine-treated (reserpine) rat hearts. Arrows, zero current level. $B$ and $C$ : means $\pm \mathrm{SE}$ current densityvoltage $(V)$ relationships for currents recorded in myocytes from control $(n=34)$ and reserpine-treated $(n=37)$ rat hearts with the protocol shown in the inset. $B$ : peak transient outward potassium current $\left(I_{\text {to }}\right) ; C$ : sustained outward potassium current $\left(I_{\text {sus }}\right)$. ${ }^{*} P<$ 0.05 , $* * P<0.005$, and $* * * P<0.001$, values significantly different from control. voltage step, a large sustained component of outward current $\left(I_{\text {sus }}\right)$ remained.

$I_{\text {to }}$ was markedly decreased by reserpine treatment. Current density-voltage relationships, determined as indicated in METHODS, are shown in Fig. $2 B$. In both groups, $I_{\text {to }}$ activation began at around $-20 \mathrm{mV}$ and increased with depolarization. In cells from reserpinetreated rats, $I_{\text {to }}$ at $+65 \mathrm{mV}$ was $51 \%$ of that of control cells $(9.4 \pm 0.6 \mathrm{pA} / \mathrm{pF}$ in reserpine-treated animals vs. $18.3 \pm 1.3 \mathrm{pA} / \mathrm{pF}$ in controls). $I_{\text {to }}$ inactivation was best fitted by the sum of two exponential components and a noninactivating component. Inactivation time constants, determined at $+65 \mathrm{mV}$, for the fast and slow components were, respectively, $48 \pm 2$ and $296 \pm 22 \mathrm{~ms}$ $(n=34)$ for controls and $48 \pm 2$ and $380 \pm 35 \mathrm{~ms}$ for reserpine-treated rats $(n=37)$. Despite a slight tendency of the slow inactivation time constant to increase, no significant differences in fast and slow time constants were observed. The fast component of $I_{\text {to }}$ accounted for $\sim 64 \%$ of the current. Densities of the fast and slow components of $I_{\text {to }}$ (measured at the peak of $I_{\text {to }}$, at $+65 \mathrm{mV}$ ) were, respectively, $13.9 \pm 1.1$ and $4.2 \pm 0.5$ $\mathrm{pA} / \mathrm{pF}$ in control animals. In reserpine-treated rats, they were $6.9 \pm 0.5$ and $2.2 \pm 0.2 \mathrm{pA} / \mathrm{pF}(P<0.001)$. So catecholamine depletion induced decreases of similar order in the two components of $I_{\text {to }}(50.4 \%$ for the fast component and $52.4 \%$ for the slow component).

In some experiments, right and left ventricular cells were separated at the end of the dissociation procedure. $I_{\text {to }}$ density measurements (at $+65 \mathrm{mV}$ ) were $27.0 \pm 3.2 \mathrm{pA} / \mathrm{pF}(n=11)$ for the right ventricle and $16.1 \pm 2.4 \mathrm{pA} / \mathrm{pF}(n=15)$ for the left ventricle in control rat hearts, consistent with those described by Wickenden et al. (40). After reserpine treatment, the mean densities for $I_{\text {to }}$ were $13.1 \pm 1.7 \mathrm{pA} / \mathrm{pF}(n=10)$ for the right ventricle and $7.8 \pm 1.8 \mathrm{pA} / \mathrm{pF}(n=14)$ for the left ventricle. So in both ventricles catecholamine depletion induced similar decreases $(51.3 \%$ in the left ventricle and $51.5 \%$ in the right ventricle) in $I_{\text {to }}$ amplitude and, therefore, experiments were performed with cells from both ventricles indifferently.

The possibility that reserpine treatment altered $I_{\text {sus }}$ was investigated. $I_{\text {sus }}$ was measured at the end of 1 -s depolarizing pulses, when $I_{\text {to }}$ was mostly inactivated. $I_{\text {sus }}$ was slightly but significantly lower in cells from reserpine-treated rats than in cells from control rats for potentials positive to $+30 \mathrm{mV}$. To study this putative effect of reserpine treatment in more detail, we increased the resolution of recording of $I_{\text {sus }}$ using a double-pulse protocol (the first 500-ms pulse was ap- 
plied from -80 to $+50 \mathrm{mV}$ and was followed $5 \mathrm{~ms}$ later by a second $500-\mathrm{ms}$ pulse from $-40 \mathrm{mV}$ to various test potentials) to inactivate $I_{\text {to }}$. With this protocol, we observed no significant changes in $I_{\text {sus }}$ density for any potentials tested.

We checked that the decrease in $I_{\text {to }}$ density in the reserpine-treated rats was not due to an effect of reserpine in two sets of experiments. In the first set, $I_{\text {to }}$ was measured during direct application of reserpine to control myocytes for $5 \mathrm{~min}$. We observed a small, nonsignificant increase in $I_{\text {to }}(3.9 \pm 3.9 \%, n=5)$. In another set of experiments, $I_{\text {to }}$ amplitude was studied in rats given a single injection of reserpine $2 \mathrm{~h}$ before their death. There was no significant difference in $I_{\text {to }}$ density between control $(18.3 \pm 1.3 \mathrm{pA} / \mathrm{pF}, n=34)$ and reserpine-treated animals $(20.5 \pm 2.5 \mathrm{pA} / \mathrm{pF}, n=7)$. So the lower $I_{\text {to }}$ density observed in reserpine-treated rats was not due to an acute effect of reserpine.

The decrease in $I_{\text {to }}$ density routinely observed with cardiac hypertrophy has been consistently associated with a large increase in cell size, usually detected by monitoring cell membrane capacitance. To rule out the possibility that reserpine treatment could also induce cardiac hypertrophy, we measured cell membrane capacitance as described in METHODS. It was $164 \pm 6 \mathrm{pF}$ $(n=42)$ in control cells and $132 \pm 4 \mathrm{pF}(n=41)$ in cells from reserpine-treated animals, indicating that cell size was significantly lower $(-18 \%)$ in reserpinetreated rats $(P<0.001)$. This decrease in cell membrane capacitance was associated with a lower heart weight $(784 \pm 60 \mathrm{mg}$ in reserpine-treated rats vs.
$947 \pm 123 \mathrm{mg}$ in controls, $n=5, P<0.05)$. A decrease in membrane capacitance has also been reported in other models of denervation $(12,21,34)$.

Voltage-dependent activation, steady-state inactivation, and recovery from inactivation of $I_{t o}$ in myocytes of reserpine-treated rats. We used the $G_{\max }$ values obtained with the procedure described in METHODs to plot normalized whole cell conductance $\left(G / G_{\max }\right)$ against the membrane potential for myocytes from both control and reserpine-treated rats (Fig. $3 B$ ). The conductancevoltage activation curve for reserpine-treated animals was shifted by $6.7 \mathrm{mV}$ toward negative potentials $\left(V_{0.5}=14.8 \pm 1.1 \mathrm{mV}, n=33\right.$, in control vs. $8.1 \pm 2.0$ $\mathrm{mV}, n=30$, in reserpine-treated rats) and had a higher but not significantly different $k(12.6 \pm 0.6 \mathrm{mV}$ in control vs. $14.0 \pm 0.8 \mathrm{mV}$ in reserpine-treated animals). The small but significant $(P<0.005)$ difference in $V_{0.5}$ between reserpine-treated and control rats cannot account for the decrease of $I_{\text {to }}$ in reserpine-treated rats; indeed, it would be more likely to produce an increase in $I_{\text {to }}$.

To determine the voltage dependence of $I_{\text {to }}$ inactivation, the membrane was held for $2 \mathrm{~s}$ at various membrane potentials between -110 and $+17.5 \mathrm{mV}$. A test pulse at $+25 \mathrm{mV}$ was then applied. Figure $3 \mathrm{~A}$ shows current traces obtained with this stimulation protocol. The steady-state inactivation-voltage relationship (current/maximal current) was shifted (by $2.2 \mathrm{mV}$ ), but not significantly, toward negative potentials for reserpine-treated rats, but $k$ was unaffected (Fig. $3 B$ ). $V_{0.5}$ and $k$ were $-39.7 \pm 2.1$ and $-4.2 \pm 0.2 \mathrm{mV}$, respec-
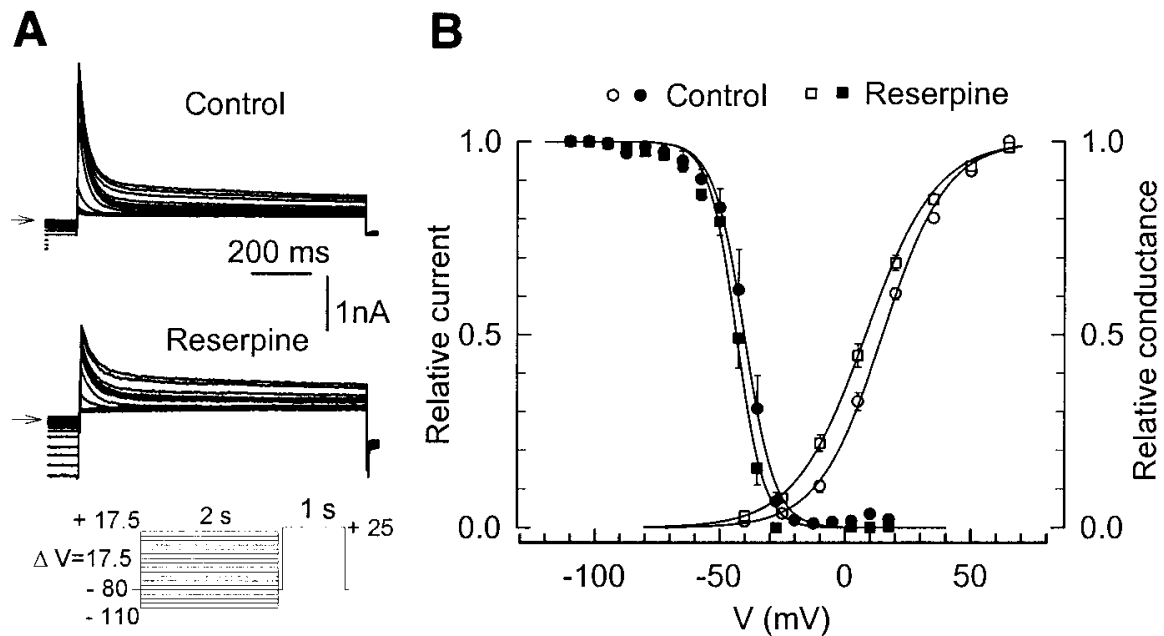

Fig. 3. Voltage-dependent activation and steady-state inactivation of $I_{\text {to }}$. A: representative current traces elicited by the stimulation protocol (shown in the inset) used to determine steady-state inactivation (see text) in a control myocyte [membrance capacitance $\left(\mathrm{C}_{\mathrm{m}}\right)=148 \mathrm{pF}$ ] and in a myocyte $\left(\mathrm{C}_{\mathrm{m}}=175 \mathrm{pF}\right)$ from a reserpine-treated rat. $B$ : steady-state inactivation-voltage relationships of $I_{\text {to }}$ (solid symbols) in control cells $(n=7)$ and in cells $(n=5)$ from reserpine-treated rats The curves were fitted to experimental data according to the following Boltzmann equation: $I / I_{\max }=1 /\left\{1+\exp \left[-\left(V_{\mathrm{m}}-V_{0.5}\right) / k\right]\right\}$, where $I$ is current, $I_{\max }$ is maximal current, $V_{\mathrm{m}}$ is the membrane potential, $V_{0.5}$ is the potential at which conductance is one-half maximally activated, and $k$ is the slope factor; $V_{0.5}=-39.7$ $\mathrm{mV}$ and $k=-4.2 \mathrm{mV}$ for control cells vs. $V_{0.5}=-42.4 \mathrm{mV}$ and $k=-4.2 \mathrm{mV}$ for cells from reserpine-treated rats. $B$ : activation-voltage relationships (open symbols) showing normalized chord conductance $\left(G / G_{\max }\right)$ of $I_{\text {to }}$ plotted vs. the membrane potential for control $(n=33)$ and reserpine-treated rats $(n=30)$. The curves were fitted to experimental data using the procedures described in the text. The values of $V_{0.5}$ and $k$ were $14.8 \pm 1.1$ and $12.6 \pm$ $0.6 \mathrm{mV}$, respectively, for control myocytes and $8.1 \pm 2.0$ and $14.0 \pm 0.8 \mathrm{mV}$, respectively, for myocytes from reserpine-treated rats. The curves were compared by determining the $V_{0.5}$ and $k$ for each individual cell and by comparing the mean $V_{0.5}$ and $k$ values for each group. 

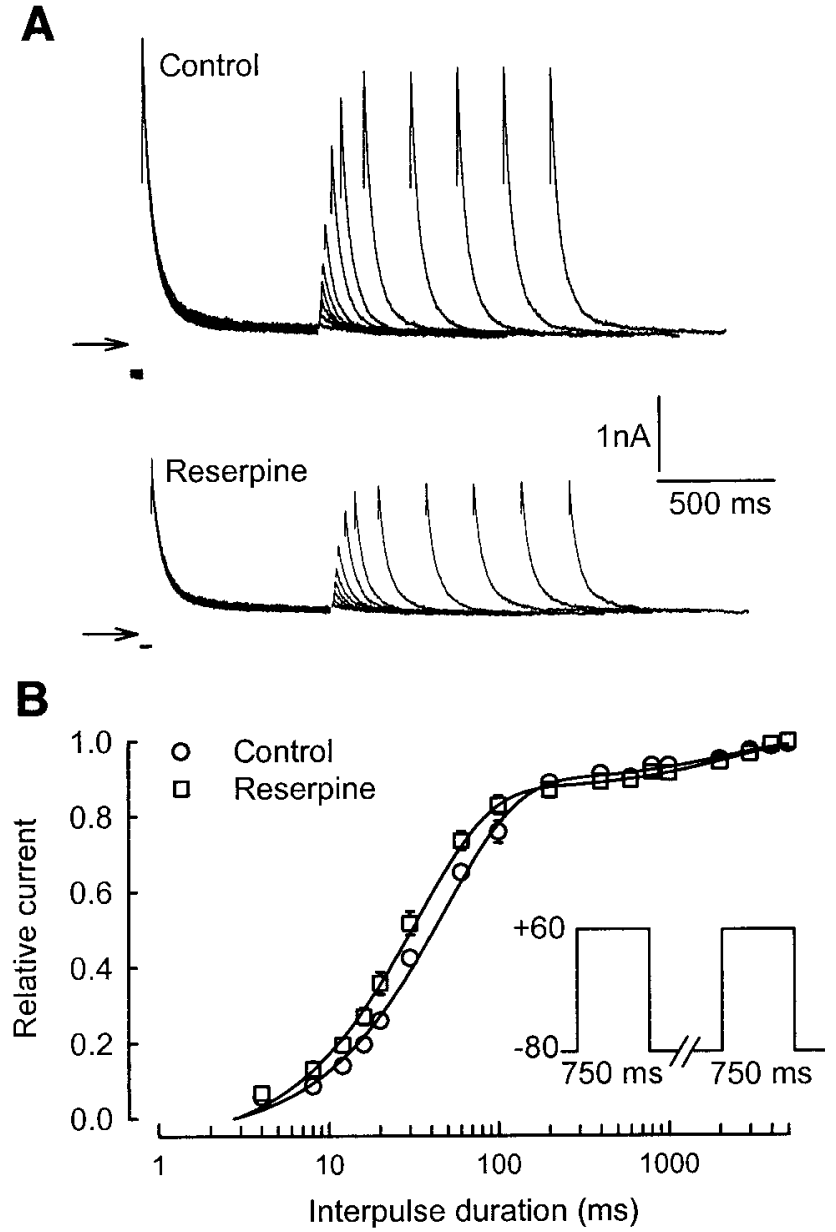

Fig. 4. Recovery from inactivation of $I_{\text {to. }}$ A: two identical pulses (protocol shown in the inset) with various interval durations (in ms: $4,8,12,16,16,20,30,60,100,200,400,600,800,1,000,2,000,3,000$, 4,000 , and 5,000 ) were applied every $10 \mathrm{~s}$ to determine the time course of $I_{\text {to }}$ recovery. Superimposed current traces were recorded in a myocyte from a control animal (top; $\mathrm{C}_{\mathrm{m}}=177 \mathrm{pF}$ ) and in a myocyte from a reserpine-treated animal (bottom; $\mathrm{C}_{\mathrm{m}}=141 \mathrm{pF}$ ). Arrows, zero current level. $B$ : normalized magnitude of $I_{\text {to }}$ elicited by the second pulse plotted against the interpulse duration for myocytes from control $(n=5)$ and reserpine-treated rats $(n=6)$. Data were fitted with the following two-exponential function: $1-A \exp \left(-t / \tau_{1}\right)-B$ $\exp \left(-t / \tau_{2}\right)$, where $t$ is the interpulse duration, $\tau_{1}$ and $\tau_{2}$ are the two time constants of recovery, and $A$ and $B$ are constants. tively, in control and $-42.4 \pm 1.5$ and $-4.2 \pm 0.3 \mathrm{mV}$, respectively, in reserpine-treated animals.

Recovery from inactivation was determined with a double-pulse protocol as described in METHODS. The control current elicited by the first pulse was highly reproducible. The peak outward current elicited by the second pulse was zero for a pulse interval of $4 \mathrm{~ms}$ and increased rapidly with increasing pulse interval (Fig. $4 A$ ). The curves (Fig. $4 B$ ) show a two-exponential fit to the data from control and reserpine-treated myocytes. The fast component accounted for $89.1 \%$ of the current in control and $90.3 \%$ in reserpine-treated rats, showing no variation between the two groups. The time constants of recovery (fast and slow, respectively) for $I_{\text {to }}$ were $47 \pm 5$ and $2,293 \pm 335 \mathrm{~ms}$ for control cells and $33 \pm 4$ and $2,263 \pm 264 \mathrm{~ms}$ for cells from reserpinetreated rats. These differences were not significant.

Thus the decrease in $I_{\text {to }}$ density in reserpine-treated myocytes was not due to differences in the kinetic parameters of the current. This decrease may result from a lack of trophic effects of norepinephrine, secondary to acute sympathetic denervation, as has been suggested in dogs infected with the agent of Chagas' disease (14). It was therefore of interest to test whether $I_{\text {to }}$ density in reserpine-treated myocytes was restored to control levels by exposure to adrenergic agonists.

Effects on $I_{t o}$ of application of norepinephrine in reserpine-treated rats. We investigated whether the decrease in $I_{\text {to }}$ observed in reserpine-treated rats could be restored by long-term application of norepinephrine as described in other animal models where a decrease in $I_{\text {to }}$ was associated with denervation (13). Myocytes from control and reserpine-treated animals were maintained in $0.5 \mathrm{mM} \mathrm{CaCl} 2$-Tyrode solution. Cells were treated with adrenergic agonist by incubating with norepinephrine $(0.5$ or $10 \mu \mathrm{M})$ for $7-10 \mathrm{~h}$. The cells were then washed three times with $0.5 \mathrm{mM} \mathrm{CaCl} 2^{-}$ Tyrode solution, and currents were recorded. The application of $0.5 \mu \mathrm{M}$ norepinephrine in control cells had no effect on $I_{\text {to }}$ density, whereas application of $10 \mu \mathrm{M}$ induced a decrease in $I_{\text {to }}$ density (Fig. 5A). Current density values for $I_{\text {to }}$ at $+65 \mathrm{mV}$ were $22.7 \pm 3.1 \mathrm{pA} / \mathrm{pF}$ $(n=5)$ for control, $21.8 \pm 4.8 \mathrm{pA} / \mathrm{pF}(n=6)$ after
Fig. 5. Effect on $I_{\text {to }}$ density of long-term application of norepinephrine (NE). The effects of incubation with 0.5 and $10 \mu \mathrm{M}$ NE on mean current density-voltage relationships for $I_{\mathrm{to}}$ (same stimulation protocol as shown in Fig. 2) are shown. $I_{\text {to }}$ densities were measured in myocytes from reserpine-treated rats $(B)$ and from control myocytes $(A)$. Cells were incubated with drug for $7-10 \mathrm{~h}$ in $0.5 \mathrm{mM} \mathrm{CaCl}_{2-}$ Tyrode solution.

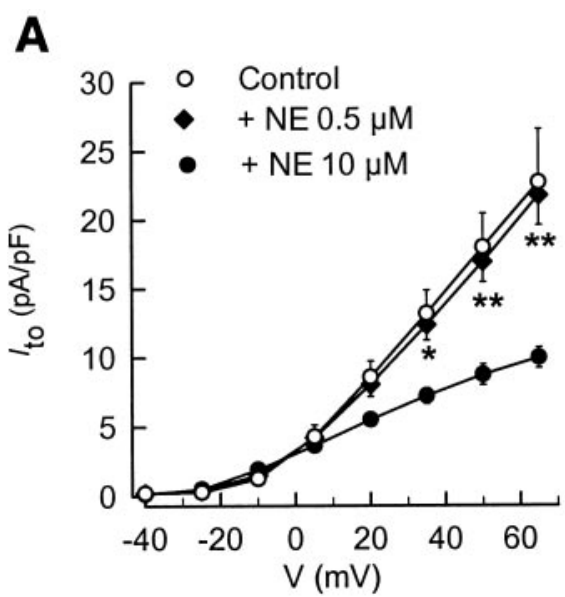

B

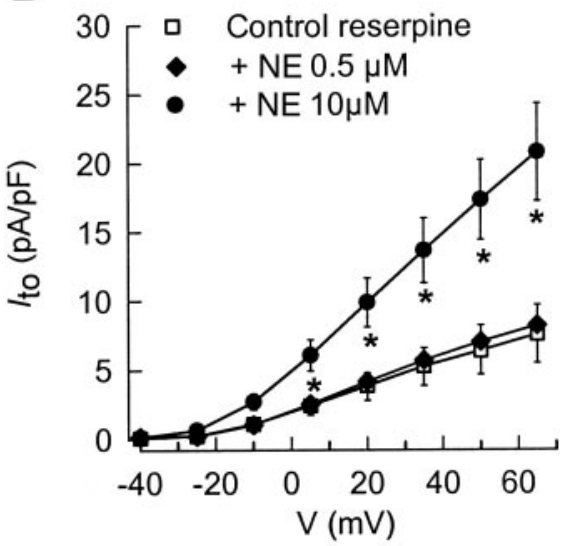


incubation with $0.5 \mu \mathrm{M}$ norepinephrine, and $10.0 \pm 0.8$ $\mathrm{pA} / \mathrm{pF}(n=6)$ with $10 \mu \mathrm{M}$ norepinephrine. In contrast, in cells from reserpine-treated rats, incubation with 10 $\mu \mathrm{M}$ norepinephrine induced an increased in $I_{\text {to }}$ density such that $I_{\text {to }}$ density was restored to control values. Norepinephrine $(0.5 \mu \mathrm{M})$ had no effect on $I_{\text {to }}$ density (Fig. 5B). Current density values for $I_{\text {to }}$ at $+65 \mathrm{mV}$ were $7.6 \pm 2.1 \mathrm{pA} / \mathrm{pF}(n=7)$ in myocytes from reserpine-treated rats not exposed to the adrenergic agonist, $8.2 \pm 1.5 \mathrm{pA} / \mathrm{pF}(n=10)$ in myocytes exposed to $0.5 \mu \mathrm{M}$ norepinephrine, and $20.8 \pm 3.5 \mathrm{pA} / \mathrm{pF}(n=5)$ in myocytes exposed to $10 \mu \mathrm{M}$ norepinephrine. Steady-state inactivation-voltage relationships were not significantly affected by addition of $10 \mu \mathrm{M}$ norepinephrine. Values for $V_{0.5}$ and $k$ were $-43.2 \pm 1.7$ and $-6.3 \pm 1.5$ $\mathrm{mV}$ for control $(n=4)$ with norepinephrine and $-45.5 \pm 0.7$ and $-5.3 \pm 0.5 \mathrm{mV}$ for reserpine-treated rats with norepinephrine $(n=4)$. Our results favor a decrease in the number of ionic channels generating $I_{\text {to }}$ in reserpine-treated rats. The restoration of $I_{\text {to }}$ density by norepinephrine could be due to reexpression of such channels. To test this point, we measured the effect of norepinephrine in the presence of actinomycin D (1.6 $\mu \mathrm{M})$, a well-known inhibitor of transcription. In the presence of actinomycin $\mathrm{D}$, the restoration of $I_{\text {to }}$ density by norepinephrine was abolished. Current density values for $I_{\text {to }}$ at $+65 \mathrm{mV}$ were $9.9 \pm 2.2 \mathrm{pA} / \mathrm{pF}(n=9)$ for myocytes from reserpine-treated rats not exposed to norepinephrine, $19.2 \pm 3.1 \mathrm{pA} / \mathrm{pF}(n=5)$ for myocytes exposed to norepinephrine, and $9.7 \pm 4 \mathrm{pA} / \mathrm{pF}(n=5)$ for myocytes incubated with both norepinephrine and actinomycin D. In control cells, the presence of actinomycin D did not prevent the inhibitory effect of norepinephrine on $I_{\text {to }}$ density, and actinomycin D alone had no effect. Current density values for $I_{\text {to }}$ at $+65 \mathrm{mV}$ were $10.0 \pm 0.8 \mathrm{pA} / \mathrm{pF}(n=6)$ for myocytes exposed to norepinephrine and $11.0 \pm 2.8 \mathrm{pA} / \mathrm{pF}(n=7)$ for myocytes incubated with both norepinephrine and actinomycin D.

Effect of NPY on the restoration of $I_{t o}$ by norepinephrine. NPY is a neurotrophic factor involved in sympathetic innervation. It has been reported that chronic conditioning of noninnervated myocytes with NPY simulates the effect of sympathetic innervation by inducing an $\alpha$-inhibitory response to phenylephrine (39) and that NPY affects the functional expression of the adrenergic signaling cascade (37). In our model, micromolar concentrations of norepinephrine did not restore $I_{\text {to }}$ to control values, as reported for other model of denervation $(13,14)$. We investigated whether NPY helped to restore $I_{\text {to }}$ in the presence of a low concentration of norepinephrine; no effect was observed in control conditions.

We investigated the effect of a low concentration of norepinephrine $(0.5 \mu \mathrm{M})$ in the presence of NPY $(0.1$ $\mu \mathrm{M})$. If control cells were incubated in the presence of NPY alone or in the presence of both NPY and norepinephrine, we observed no significant effect on $I_{\text {to }}$ density (Fig. $6, A$ and $C$ ). Values of $I_{\text {to }}$ densities at $+65 \mathrm{mV}$ were $22.7 \pm 3.1 \mathrm{pA} / \mathrm{pF}(n=5)$ for control cells, $22.3 \pm$ $3.9 \mathrm{pA} / \mathrm{pF}(n=6)$ with NPY, and $18.6 \pm 2.7 \mathrm{pA} / \mathrm{pF}(n=$
6) with NPY and norepinephrine. In cells from reserpine-treated animals, NPY alone had no effect on $I_{\text {to }}$, whereas incubation with both NPY and a low concentration of norepinephrine restored $I_{\text {to }}$ values to the control level (Fig. 6, $B$ and $D$ ). At $+65 \mathrm{mV}, I_{\text {to }}$ densities were $7.6 \pm 2.1 \mathrm{pF} / \mathrm{pA}(n=7)$ for cells from reserpinetreated animals, $9.1 \pm 1.3 \mathrm{pA} / \mathrm{pF}(n=7)$ in the presence of NPY, and $15.6 \pm 0.8 \mathrm{pA} / \mathrm{pF}(n=7)$ in the presence of both NPY and $0.5 \mu \mathrm{M}$ norepinephrine. Thus NPY is able to potentiate the effect of norepinephrine in cells from reserpine-treated rats. The steady-state inactivation-voltage relationship in cells from reserpine-treated rats incubated with NPY and norepinephrine did not differ significantly from that of cells from reserpine-treated rats. $V_{0.5}$ and $k$ were $-40.9 \pm 1.4$ and $-6.2 \pm 1.4 \mathrm{mV}(n=5)$. The two time constants of recovery from inactivation after incubation with NPY and norepinephrine did not differ significantly from those for cells from reserpine-treated animals: $31.7 \pm 5.6 \mathrm{~ms}$ for the fast component and $2,011 \pm 214 \mathrm{~ms}(n=4)$ for the slow component. Thus the kinetic parameters of $I_{\text {to }}$ were not changed by incubation with both NPY and norepinephrine. $I_{\text {to }}$ was also restored to control values by incubating cells with norepinephrine and NPY (13-36), a NPY agonist selective for $\mathrm{Y}_{2}$ receptors (at $+65 \mathrm{mV}, I_{\text {to }}$ density was $19.2 \pm 1.1 \mathrm{pA} / \mathrm{pF}, n=8)$.

In other models of catecholamine depletion, restoration of $I_{\text {to }}$ by norepinephrine occurred either via the $\alpha$-adrenergic (14) or $\beta$-adrenergic $(13,33)$ pathway. We therefore tried to determine whether the restoration of $I_{\text {to }}$ we observed was mediated by activation of $\alpha$ - or $\beta$-adrenergic receptors in our model. The effects of norepinephrine and NPY were evaluated after pretreatment with $1 \mu \mathrm{M}$ prazosin, an $\alpha_{1}$-adrenergic receptor antagonist, or propranolol $(1 \mu \mathrm{M})$, a $\beta$-adrenergic receptor antagonist. The effects of norepinephrine and NPY on $I_{\text {to }}$ were blocked in the presence of prazozin (at $+65 \mathrm{mV}, I_{\text {to }}$ density was $10.9 \pm 2.2 \mathrm{pA} / \mathrm{pF}, n=5$ ) but not in the presence of propranolol $(15.0 \pm 1.3 \mathrm{pA} / \mathrm{pF}$, $n=5$ ). Thus the restoration of $I_{\text {to }}$ required the $\alpha_{1^{-}}$ adrenergic pathway in our model.

\section{DISCUSSION}

Cardiac catecholamine depletion, induced by reserpine treatment in Wistar rats, resulted in a marked decrease in tissue norepinephrine content. This decrease in norepinephrine content was correlated with 1) a lengthening of the duration of the ventricular action potential plateau in the isolated perfused heart and 2 ) a decrease in $I_{\text {to }}$ density by $\sim 50 \%$, with no marked change in kinetic parameters, in isolated ventricular myocytes. Reserpine treatment also reduced membrane capacity. Long-term application of $10 \mu \mathrm{M}$ norepinephrine reversed the observed decrease in $I_{\text {to }}$ density via an effect on the $\alpha$-adrenergic cascade. Low concentrations of norepinephrine $(0.5 \mu \mathrm{M})$ did not restore the $I_{\text {to }}$ amplitude unless NPY was also present.

Chronic depletion of norepinephrine is usually induced either by treatment with chemical substances 
A
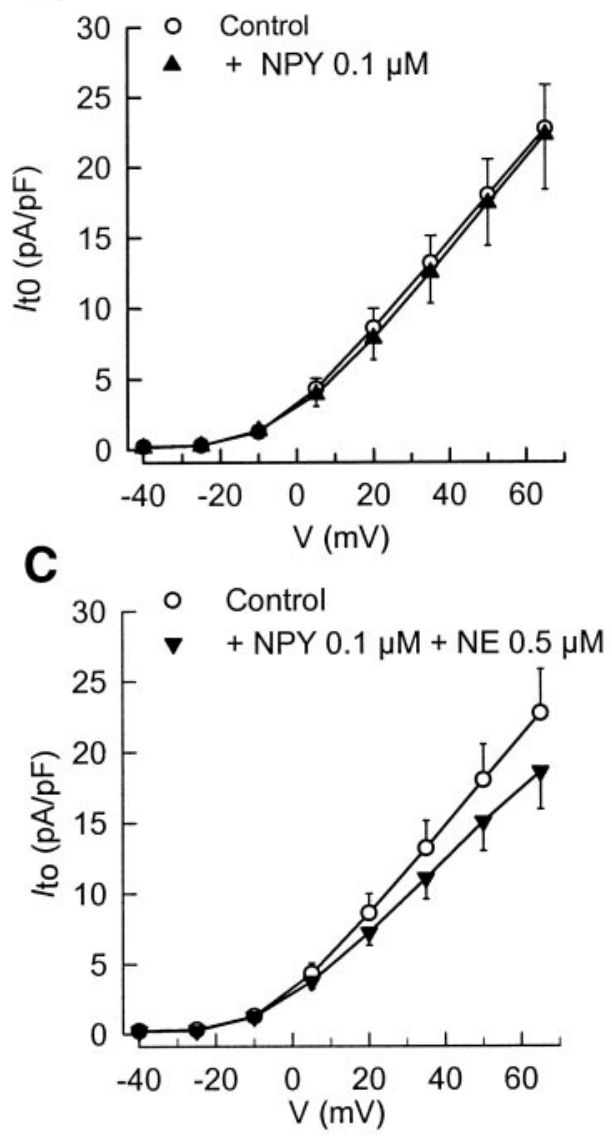

B
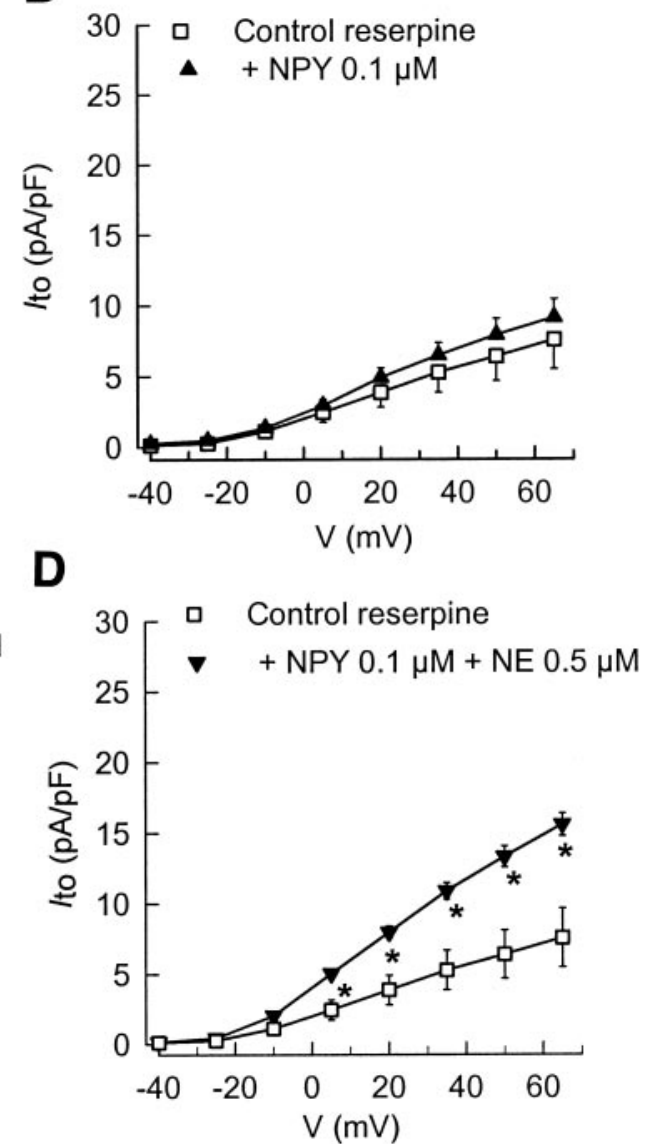

Fig. 6. Effect of a low concentration of $\mathrm{NE}$ in the presence of neuropeptide $\mathrm{Y}$ (NPY). The effects of incubation of NPY $(A$ and $B)$ and NPY with $0.5 \mu \mathrm{M} \mathrm{NE}(C$ and $D$ ) in cells from control hearts $(A$ and $C$ ) and in cells from reserpinetreated rats $(B$ and $D)$ on mean current density-voltage relationships for $I_{\text {to }}$ (same stimulation protocol as shown in Fig. 2) are shown. (reserpine, 6-hydroxydopamine, guanethidine, or phenol) or by surgical denervation. We chose to use reserpine because 1) this substance has no effect on $I_{\text {to }}$ even if applied directly to the cell or injected $2 \mathrm{~h}$ before the animal is killed and 2) this model of catecholamine depletion is the most thoroughly documented in the literature $(20,38)$. Reserpine treatment is well known to decrease tissue norepinephrine content. The 97\% decrease in norepinephrine content observed in this study is similar to the results reported by Rice et al. (38) for rat ventricular muscle. Endogenous norepinephrine determinations have not been reported in other models in which a decrease in sympathetic denervation is correlated with a decrease in $I_{\text {to }}$ except in newborn rat myocytes, in which a 35\% decrease in norepinephrine content (relative to placebo) has been observed in rats treated with antibody directed against nerve growth factor (21).

Action potential duration was $\sim 50 \%$ longer after reserpine treatment than in controls, and 4-AP normalized action potential duration. Liu et al. (21) also described a $26 \%$ increase in the ventricular action potential duration of hearts from newborn rats treated with antibody against nerve growth factor, and a lengthening of the activation recovery interval, which is correlated with action potential duration, has also recently been reported in phenol-induced denervation in the rabbit heart (43).
Some studies have reported changes in ionic current during development of innervation. Changes in calcium current have been described in neonatal rat cells cultured with or without sympathetic ganglia or neurons. Innervated myocytes show an increase in calcium current of $\sim 50 \%(29,35)$. Similar studies (44) have reported an increase in sodium current in innervated neonatal rat ventricular cells. $I_{\text {to }}$ density quadruples between 1 and 10 days in ventricular cells (18), a period corresponding to maturation of sympathetic innervation (24). Thus development of innervation increased ionic currents involved in the decay of action potential. The opposite phenomenon, denervation, might therefore be expected to result in a decrease in this currents. No previous data are available concerning inward currents during denervation. However, our study of reserpine-treated rats show a decrease of $\sim 20 \%$ in the maximum upstroke velocity of the action potential with no change in resting potential, suggesting a decrease of sodium current in the denervated rat hearts.

We observed that $I_{\text {to }}$ was $\sim 50 \%$ lower in reserpinetreated rats than in control animals. Decreases in $I_{\text {to }}$ of $20-50 \%$ have also been described in other models of cardiac sympathetic denervation (11, 13, 14, 21, 31). The fast and slow components of $I_{\text {to }}$ both decreased by $\sim 50 \%$ in response to reserpine treatment. The values obtained for these components were consistent with 
those reported by Wickenden et al. (40) in the rat ventricular septum. Like the two time constants of $I_{\text {to }}$ inactivation, they were not significantly affected by reserpine treatment, a result consistent with that reported in other models of cardiac denervation (12-14). Positive (12), negative (our study), or no shifts (21) in the activation-voltage relationship were also reported. We observed no other significant change in other kinetic parameters (inactivation-voltage relationships and recovery from inactivation). Changes occurred in some of the other models, but these changes cannot account for the observed decrease in $I_{\text {to }}$ density. Our results suggest that the decrease in $I_{\text {to }}$ density in reserpine-treated rats results from a decrease in the number of functional ionic channels responsible for this current.

Long-term exposure of control myocytes to norepinephrine induced a decrease in $I_{\text {to }}$ density, as previously reported (41), mediated by a PKC-dependent (2) or -independent pathway (4). In contrast, the application of norepinephrine to cells from reserpine-treated rats increased $I_{\text {to }}$ density. Similar increases have been reported in other models of cardiac denervation $(13,14$, $34)$. This contradictory effect of norepinephrine between control cells and cells from reserpine-treated rats suggested two different pathways for norepinephrine action. In cells from reserpine-treated rats, we demonstrated that the stimulating effect of norepinephrine was abolished by the presence of an inhibitor of transcription such as actinomycin D. In control cells, the inhibitory effect of norepinephrine was not prevented by actinomycin $D$. So it could be suggested that the stimulatory effect of norepinephrine on $I_{\text {to }}$ occurred via a reexpression of $I_{\text {to }}$ channels, whereas in control cells the inhibition of $I_{\text {to }}$ by norepinephrine was due to its classical effect via phosphorylation process. Such stimulation of $I_{\text {to }}$ by norepinephrine also needed time $(>6 \mathrm{~h})$ to develop, as reported in Chagasic myocytes (14); such a duration is more compatible with a process of channel reexpression. This restoration of $I_{\text {to }}$ density by norepinephrine is mediated via the $\beta$-adrenergic pathway $(13,34)$, whereas in Chagasic myocytes this effect is mediate by $\alpha_{1}$-adrenoceptor stimulation of PKC via a pertussis-insensitive signaling cascade (14). In our model, $I_{\text {to }}$ was restored by means of an $\alpha$-adrenergic pathway because it was inhibited by prasozin. This difference may be due to the $\beta$-adrenoceptor downregulation described in Chagasic myocytes (13) and in reserpine-treated rats (6). Such an effect could result in the overestimation of $\alpha$-adrenoceptor activity in these cells.

In our reserpine-treated rat model, a diminution of $I_{\text {to }}$ was associated with a depletion of myocardial norepinephrine. In myocardial infarction $(17,36)$ and heart failure (25), a decrease in $I_{\text {to }}$ was reported, whereas a stimulation of the sympathetic nervous system was also reported. These observations raise the question as to whether reductions of $I_{\text {to }}$ were linked to chronic stimulatory effects of catecholamine (29). Until now, this point received no answer. Comparison of these models pointed out important differences. In reserpine-treated rats, heart rate and pressure are decreased (18) and plasma norepinephrine concentration did not change significantly $(412 \pm 87 \mathrm{pg} / \mathrm{ml}$ in control vs. $478 \pm 97 \mathrm{pg} / \mathrm{ml}$ in reserpine-treated rats) or even decreased for longer time treatment (10). In heart failure, there was an increase in heart rate and pressure and an increase in plasma norepinephrine concentration (8), but there was a decrease in myocardial norepinephrine content (5). So in reserpine-treated rats we observed no sign of stimulation of the nervous sympathetic system. At the present time, we have no explanation concerning this difference. The main observed similarities between these two models were a decrease in $I_{\text {to }}$ and a decrease in myocardial norepinephrine content. However, further studies will be necessary to establish a direct link between these two decreases.

In our experiments, only a high concentration of norepinephrine $(10 \mu \mathrm{M})$ restored $I_{\text {to }}$ to control values in reserpine-treated rats, whereas in other models lower concentrations have been reported to have such an effect. The low concentration $(0.5 \mu \mathrm{M})$ of norepinephrine restored $I_{\text {to }}$ to control values in the presence of NPY. The peptide is colocalized and coreleased with norepinephrine in sympathetic nerve terminals and is widely distributed in the mammalian heart (1), and in reserpine-treated rats a 50\% decrease in the NPY content of the heart has been reported concomitantly with a decreased in norepinephrine content (15). Such a potentiating effect of NPY has also been reported in smooth muscle cells and in cardiac cells. In neonatal cardiac cells, the $V_{0.5}$ of the activation curve of the pacemaker current is shifted from -77 to $-88 \mathrm{mV}$ if cells are cocultured with sympathetic nerves. Incubation with $1 \mu \mathrm{M}$ norepinephrine alone does not to induce such a shift of the activation curve, but in the presence of both norepinephrine and NPY the $V_{0.5}$ of the activation curve is shifted $(-94 \mathrm{mV})$. Thus, in this model, NPY is necessary to induce the shift of the activation curve (37).

A consensus is emerging that the slow component of $I_{\text {to }}$ is encoded by the Kv1.4 channel gene, whereas the fast component is generated principally by the $\mathrm{Kv} 4.2$ and/or Kv4.3 genes (for reviews, see Refs. 28 and 30). In our model, both components of $I_{\text {to }}$ decreased to the same extent. For the fast component, it is unclear whether Kv4.2 predominates over Kv4.3. The only evidence for the predominance of $\mathrm{Kv} 4.2$ is that the $V_{0.5}$ of the inactivation curve determined in our conditions is similar to that reported for $\mathrm{Kv} 4.2$ in mouse $\mathrm{L}$ cell lines (42). Incubation with norepinephrine restored the $I_{\text {to }}$ amplitude with no effect on the kinetic parameters of the current, and this effect is abolished by actinomycin $\mathrm{D}$ in cells from reserpine-treated rats. The data support the idea that incubation with norepinephrine restore the expression of $\alpha$-subunit genes. This is only speculative and additional studies are required to analyze the changes in $I_{\text {to }}$ gene expression induced by reserpine treatment at the mRNA and protein levels.

The results of this study are well explained considering that, in the adult cardiac cell, $I_{\text {to }}$ density is regulated by norepinephrine released from neurons by 
the $\alpha$-adrenergic cascade and this cascade is potentiated by NPY. The effect of such regulation of neural release of norepinephrine on expression of the potassium current may be of importance because it may provide a common explanation for the marked decrease in $I_{\text {to }}$ observed in the various cardiac diseases studied. The role of sympathetic innervation in other cardiac diseases in which a decrease in $I_{\text {to }}$ density has been described remains to be determined.

This work was supported by grants from University Paris XI. G. Bru-Mercier was supported by grant from the Ministère de l'Eductation Nationale, de la Recherche et de la Technologie.

\section{REFERENCES}

1. Allen JM, Gjorstrup P, Bjorkman JA, Ek L, Abrahamsson T, and Bloom SR. Studies on cardiac distribution and function of neuropeptide Y. Acta Physiol Scand 126: 405-411, 1986.

2. Apkon $\mathbf{M}$ and Nerbonne JM. $\alpha_{1}$-Adrenergic agonists selectively suppress voltage-dependent $\mathrm{K}^{+}$current in rat ventricular myocytes. Proc Natl Acad Sci USA 85: 8756-8760, 1988.

3. Benitah JP, Gomez AM, Bailly P, Da Ponte JP, Berson G, Delgado C, and Lorente P. Heterogeneity of the early outward current in ventricular cells isolated from normal and hypertrophied rat hearts. J Physiol (Lond) 469: 111-138, 1993.

4. Braun AP, Fedida D, Clark RB, and Giles WR. Intracellular mechanisms for $\alpha_{1}$-adrenergic regulation of the transient outward current in rabbit atrial myocytes. J Physiol (Lond) 431: 689-712, 1990.

5. Coulombe A, Momtaz A, Richer P, Swynghedauw B, and Coraboeuf E. Reduction of calcium-independent transient outward potassium current density in DOCA salt hypertrophied rat ventricular myocytes. Pflügers Arch 427: 47-55, 1994.

6. Cros GH, Chanez PO, McNeill JH, and Serrano JJ. Shortand long-term effects of reserpine on rat cardiac $\beta$-adrenoceptors. Gen Pharmacol 20: 277-284, 1989.

7. Dae MW, Lee RJ, Ursell PC, Chin MC, Stillson CA, and Moise NS. Heterogeneous sympathetic innervation in German shepherd dogs with inherited ventricular arrhythmia and sudden cardiac death. Circulation 96: 1337-1342, 1997.

8. Eisenhofer G, Friberg P, Rundqvist B, Quyyumi AA, Lambert G, Kaye DM, Kopin IJ, Goldstein DS, and Esler MD. Cardiac sympathetic nerve function in congestive heart failure. Circulation 93: 1667-1676, 1996.

9. Eriksson BM and Persson BA. Determination of catecholamines in rat heart tissue and plasma samples by liquid chromatography with electrochemical detection. J Chromatogr 228: 143-154, 1982.

10. Estan L, Senard JM, Tran MA, Montastruc JL, and Berlan M. Reserpine induces vascular $\alpha_{2}$-adrenergic supersensitivity and platelet $\alpha_{2}$-adrenoceptor up-regulation in dog. Br J Pharmacol 101: 329-336, 1990.

11. Freeman K, Lerman I, Kranias EG, Bohlmeyer T, Bristow MR, Lefkowitz RJ, Iaccarino G, Koch WJ, and Leinwand LA. Alterations in cardiac adrenergic signaling and calcium cycling differentially affect the progression of cardiomyopathy. J Clin Invest 107: 967-974, 2001.

12. Freeman LC, Pacioretty LM, Moise NS, Kass RS, and Gilmour RF Jr. Decreased density of Ito in left ventricular myocytes from German shepherd dogs with inherited arrhythmias. J Cardiovasc Electrophysiol 8: 872-883, 1997.

13. Gallego M, Casis E, Izquierdo MJ, and Casis O. Restoration of cardiac transient outward potassium current by norepinephrine in diabetic rats. Pflügers Arch 441: 102-107, 2000.

14. Han W, Barr SC, Pacioretty LM, and Gilmour RF Jr. Restoration of the transient outward potassium current by noradrenaline in chagasic canine epicardium. J Physiol (Lond) 500: 75-83, 1997.

15. Hanze J, Kummer W, Haass M, and Lang RE. Effect of catecholamine depletion and denervation on neuropeptide $\mathrm{Y}$ (NPY) and tyrosine-hydroxylase (TH) mRNA levels in rat sympathetic ganglia. Exp Clin Endocrinol 102: 54-59, 1994.
16. Jourdon $\mathbf{P}$ and Feuvray $\mathbf{D}$. Calcium and potassium currents in ventricular myocytes isolated from diabetic rats. $J$ Physiol (Lond) 470: 411-429, 1993.

17. Kaprielian R, Wickenden AD, Kassiri Z, Parker TG, Liu PP, and Backx PH. Relationship between $\mathrm{K}^{+}$channel downregulation and $\left[\mathrm{Ca}^{2+}\right]_{\mathrm{i}}$ in rat ventricular myocytes following myocardial infarction. J Physiol (Lond) 517: 229-245, 1999.

18. Kilborn MJ and Fedida D. A study of the developmental changes in outward currents of rat ventricular myocytes. J Physiol (Lond) 430: 37-60, 1990.

19. Komatsu Y, Constantopoulos G, Gutkowska J, Rojo-Ortega JM, and Genest J. Effects of reserpine on water, cation, and norepinephrine contents of cardiovascular tissues of normotensive dogs. Can J Physiol Pharmacol 55: 206-211, 1977.

20. Lenz SJ, Ramos BL, Stamper MC, and Wince LC. Increased potency of carbachol in isolated rat left atria after chronic reserpine pretreatment. Am J Physiol Regulatory Integrative Comp Physiol 266: R487-R495, 1994.

21. Liu QY, Rosen MR, McKinnon D, and Robinson RB. Sympathetic innervation modulates repolarizing $\mathrm{K}^{+}$currents in rat epicardial myocytes. Am J Physiol Heart Circ Physiol 274: H915-H922, 1998.

22. Lue WM and Boyden PA. Abnormal electrical properties of myocytes from chronically infarcted canine heart. Alterations in $V_{\max }$ and the transient outward current. Circulation 85: 11751188, 1992.

23. Machado CR, de Oliveira DA, Magalhaes MJ, Carvalho EM, and Ramalho-Pinto FJ. Trypanosoma cruzi infection in rats induced early lesion of the heart noradrenergic nerve terminals by a complement-independent mechanism. J Neural Transm 97: 149-159, 1994.

24. Malfatto G, Rosen TS, Steinberg SF, Ursell PC, Sun LS, Daniel S, Danilo P Jr, and Rosen MR. Sympathetic neural modulation of cardiac impulse initiation and repolarization in the newborn rat. Circ Res 66: 427-437, 1990.

25. Nabauer M, Beuckelmann DJ, and Erdmann E. Characteristics of transient outward current in human ventricular myocytes from patients with terminal heart failure. Circ Res 73: 386-394, 1993.

26. Nabauer $\mathbf{M}$ and Kaab S. Potassium channel down-regulation in heart failure. Cardiovasc Res 37: 324-334, 1998.

27. Nakayama T and Fozzard HA. Adrenergic modulation of the transient outward current in isolated canine Purkinje cells. Circ Res 62: 162-172, 1988 .

28. Nerbonne JM. Molecular basis of functional voltage-gated $\mathrm{K}^{+}$ channel diversity in the mammalian myocardium. J Physiol (Lond) 525: 285-298, 2000.

29. Ogawa S, Barnett JV, Sen L, Galper JB, Smith TW, and Marsh JD. Direct contact between sympathetic neurons and rat cardiac myocytes in vitro increases expression of functional calcium channels. J Clin Invest 89: 1085-1093, 1992.

30. Oudit GY, Kassiri Z, Sah R, Ramirez RJ, Zobel C, and Backx PH. The molecular physiology of the cardiac transient outward potassium current $\left(I_{\text {to }}\right)$ in normal and diseased myocardium. J Mol Cell Cardiol 33: 851-872, 2001.

31. Pacioretty LM, Barr SC, Han WP, and Gilmour RFJ. Reduction of the transient outward potassium current in a canine model of Chagas' disease. Am J Physiol Heart Circ Physiol 268: H1258-H1264, 1995.

32. Pacioretty LM, Cooper BJ, and Gilmour RF Jr. Reduction of the transient outward potassium current in canine X-linked muscular dystrophy. Circulation 90: 1350-1356, 1994.

33. Pacioretty LM and Gilmour RF Jr. Restoration of transient outward current by norepinephrine in cultured canine cardiac myocytes. Am J Physiol Heart Circ Physiol 275: H1599-H1605, 1998.

34. Pacioretty LM, Moïse NS, and Gilmour RF. Norepinephrine exposure restores $I_{\text {to }}$ in epicardial myocytes from dogs with inherited ventricular arrhythmias and sudden death (Abstract). Biophys J 70: A308, 1996.

35. Protas $\mathbf{L}$ and Robinson RB. Neuropeptide $\mathrm{Y}$ contributes to innervation-dependent increase in $I_{\mathrm{Ca}}$, L via ventricular Y2 receptors. Am J Physiol Heart Circ Physiol 277: H940-H946, 1999. 
36. Qin D, Zhang ZH, Caref EB, Boutjdir M, Jain P, and el-Sherif N. Cellular and ionic basis of arrhythmias in postinfarction remodeled ventricular myocardium. Circ Res 79: 461-473, 1996.

37. Qu JH, Cohen IS, and Robinson RB. Sympathetic innervation alters activation of pacemaker current $\left(I_{\mathrm{f}}\right)$ in rat ventricle. J Physiol (Lond) 526: 561-569, 2000.

38. Rice PJ, Taylor DA, Valinski WA, Head RJ, and Flemming WW. Norepinephrine depletion and sensitivity changes in rat heart induced by pretreatment with reserpine. J Pharmacol Exp Ther 240: 764-771, 1987.

39. Sun LS, Ursell PC, and Robinson RB. Chronic exposure to neuropeptide $\mathrm{Y}$ determines cardiac $\alpha_{1}$-adrenergic responsiveness. Am J Physiol Heart Circ Physiol 261: H969-H973, 1991.

40. Wickenden AD, Jegla TJ, Kaprielian R, and Backx PH. Regional contributions of $K v 1.4, K v 4.2$, and $K v 4.3$ to transient outward $\mathrm{K}^{+}$current in rat ventricle. Am J Physiol Heart Circ Physiol 276: H1599-H1607, 1999.
41. Wickenden AD, Kaprielian R, Kassiri Z, Tsoporis JN, Tsushima R, Fishman GI, and Backx PH. The role of action potential prolongation and altered intracellular calcium handling in the pathogenesis of heart failure. Cardiovasc Res 37: 312-323, 1998.

42. Yeola SW and Snyders DJ. Electrophysiological and pharmacological correspondence between Kv4.2 current and rat cardiac transient outward current. Cardiovasc Res 33: 540547, 1997.

43. Yoshioka K, Gao DW, Chin M, Stillson C, Penades E, Lesh M, O'Connell W, and Dae M. Heterogeneous sympathetic innervation influences local myocardial repolarization in normally perfused rabbit hearts. Circulation 101: 1060-1066, 2000.

44. Zhang JF, Robinson RB, and Siegelbaum SA. Sympathetic neurons mediate developmental change in cardiac sodium channel gating through long-term neurotransmitter action. Neuron 9: 97-103, 1992.

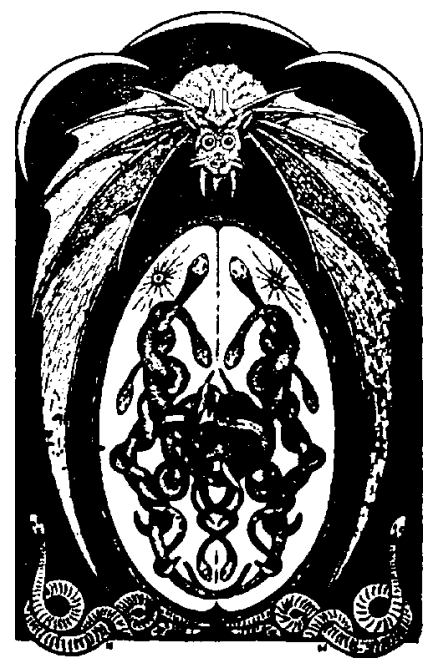

